\title{
Cerebral blood flow and metabolism in hepatic cirrhosis before and after portacaval shunt operation
}

\author{
G. BIANCHI PORRO, A. T. MAIOLO, AND P. DELlA PORTA \\ From the Institute of Medical Pathology and the Methodology Clinic, University of Milan, Italy
}

SUMMARY It has been demonstrated that cardiac output and pulmonary, gastroduodenal, pancreatic, and splenic blood flow increases after portacaval shunt operations. This report concerns a study of cerebral haemodynamics and metabolism in eight patients with cirrhosis of the liver, examined both before and after portacaval surgical anastomosis. The patients were fully alert and orientated to mental and neurological examination at all times.

In each subject the cerebral blood flow, cerebral vascular resistance, cerebral metabolic rate of oxygen and of glucose, and glucose/oxygen quotient were determined.

This investigation showed that a portacaval shunt operation is followed by a significant increase in the cerebral blood flow and a significant decrease in the cerebral vascular resistances. No important variation in the cerebral metabolic rate of oxygen was observed, but both the cerebral metabolic rate of glucose and the glucose : oxygen quotient showed significant increases.

The presence of toxic substances which, shunting the liver, enter the general circulation could be the cause of the increased cerebral blood flow, while the increase in the cerebral metabolic rate of glucose could result from a greater cerebral detoxication, for example, the cerebral synthesis of glutamine.

In patients with hepatic cirrhosis or hepatic fibrosis important haemodynamic modifications have been observed after a portacaval shunt operation; for example, an increase in cardiac output and pulmonary blood flow (Foda, Badawi, and Salah, 1964), gastroduodenal and pancreatic blood flow (Delaney, Goodale Jr, Cheng, and Wangensteen, 1965), and splenic blood flow (Gitlin, Grahame, Kreel, and Sherlock, 1968).

The present investigation concerns the behaviour of cerebral blood flow and metabolism in patients affected by hepatic cirrhosis before and after portacaval shunt operations.

\section{PATIENTS AND METHODS}

Eight subjects suffering from chronic cirrhosis of the liver were studied both before and one to 12 months after being submitted to a portacaval anastomosis operation. Each patient was at all times fully alert and orientated to mental and neurological examination.

'Presented at the third meeting of the European Association for the Study of the Liver in September 1968, at Modena, Italy.
Cerebral blood flow was measured by the nitrous oxide method of Kety and Schmidt (1948) modified with constant, continuous aspiration; the cerebral vascular resistances were calculated from the ratio between the mean arterial pressure and the cerebral blood flow. The brain metabolism was studied by determining the metabolic rate of oxygen and glucose and the glucose: oxygen quotient.

The oxygen and $\mathrm{CO}_{2}$ content of blood was determined according to the manometric method of Van Slyke and Neill (1924). The blood glucose was tested in triplicate with the glucose oxidase enzymatic method of Huggett and Nixon (1957). The cerebral metabolic rates were calculated according to the formula:

Cerebral blood flow $\times$ arterial/venous differences 100

In some of the examined cases the arterial $\mathrm{pCO}_{2}$ was determined with a Beckman gas analyser.

All studies were performed on resting, fasting patients early in the morning; arterial blood samples were drawn at the level of the femoral artery, and the venous blood samples from the bulb of the internal jugular vein.

The statistical analysis was performed by the method of paired comparison. 
RESULTS

Table I shows that cirrhotic patients have on average cerebral blood flow and cerebral vascular resistances within normal limits; after portacaval shunt a significant increase in cerebral blood flow and a significant decrease in cerebral vascular resistance were found.

TABLE I

CEREBRAL HAEMODYNAMICS BEFORE AND AFTER PORTACAVAL ANASTOMOSIS (MEAN AND SD)

$$
\text { ( } \mathrm{mm} \mathrm{Hg} \text { ) }
$$$$
\text { No. Mean Cerebral Ce:e'bral }
$$$$
\text { of Arterial Blood Flow Vascular }
$$$$
\text { Cases Pressure }(\mathrm{ml} / \mathrm{lo0} \mathrm{g} / \mathrm{min}) \quad \text { Resistance }
$$

( $\mathrm{mm} \mathrm{Hg} / \mathrm{ml}$ $100 \mathrm{~g} / \mathrm{min})$

\begin{tabular}{lrrrr}
\hline Normal & 12 & $\begin{array}{r}104 \\
\pm 11\end{array}$ & $\begin{array}{r}54.3 \\
\pm 9.1\end{array}$ & $\begin{array}{r}1.96 \\
\pm 0.38\end{array}$ \\
$\begin{array}{l}\text { Hepatic cirrhosis } \\
\begin{array}{l}\text { Before portacaval } \\
\text { anastomosis }\end{array}\end{array}$ & 8 & 99 & 63.8 & \\
& & \pm 11 & \pm 22.1 & 1.70 \\
$\begin{array}{l}\text { After portacaval } \\
\text { anastomosis }\end{array}$ & 8 & 104 & 97.7 & \pm 0.55 \\
& & \pm 13 & \pm 26.8 & $1.12^{2}$ \\
& & & & \pm 0.10
\end{tabular}

$\mathbf{P}<0.001$

${ }^{2} 0.005>P>0.001$.

In Fig. 1 it is possible to observe that both the increase in cerebral blood flow and the decrease in cerebral vascular resistance are constant; only in one case does the cerebral blood flow not increase, but in this patient the value was already higher than normal before the operation. No variation in mean arterial pressure was observed.

The mean values for the metabolic rate of oxygen and glucose and the glucose : oxygen quotient are reported in Table II; in cirrhotics the metabolic rate for oxygen and of glucose is, slightly, but not significantly, lower than that of normal subjects.
TABLE II

CEREBRAL METABOLISM BEFORE AND AFTER PORTACAVAL ANASTOMOSIS (MEAN AND SD)

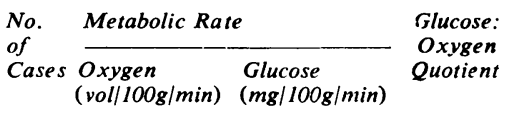

\begin{tabular}{lrrrr}
\hline Normal & 12 & $\begin{array}{r}3.76 \\
\pm 0.79\end{array}$ & $\begin{array}{r}8.24 \\
\pm 297\end{array}$ & \\
$\begin{array}{l}\text { Hepatic cirrhosis } \\
\begin{array}{l}\text { Before portacaval } \\
\text { anastomosis }\end{array}\end{array}$ & & & & \\
& 8 & 3.37 & 6.42 & 1.91 \\
$\begin{array}{l}\text { After portacaval } \\
\text { anastomosis }\end{array}$ & & \pm 1.45 & \pm 3.53 & \pm 0.64 \\
& & 4.03 & $9.86^{1}$ & $2.53^{2}$ \\
& & \pm 0.96 & \pm 2.80 & \pm 0.60
\end{tabular}

$10.02>P>0.01$.

${ }^{2} 0.01>\mathrm{P}>0.005$.

After portacaval anastomosis the metabolic rate of oxygen increases; this increase, however, is not significant $(P>0.05)$; on the other hand the increase in the metabolic rate of glucosc and in the glucose : oxygen quotient was statistically significant.

Observing each case (Fig. 2) it is possible to note that after operation only one of the eight cases showed a decrease in all three parameters.

\section{DISCUSSION}

Several factors can be discussed to explain the haemodynamic and metabolic modifications observed.

The portacaval shunt can produce the same haemodynamic effects as an arteriovenous fistula, resulting in hyperkinetic circulation with reduction in the vascular resistance and increase in the cardiac output (Foda et al, 1964), but it is well known that cerebral blood flow is slightly affected by variations in the cardiac index (Nylin, 1961).
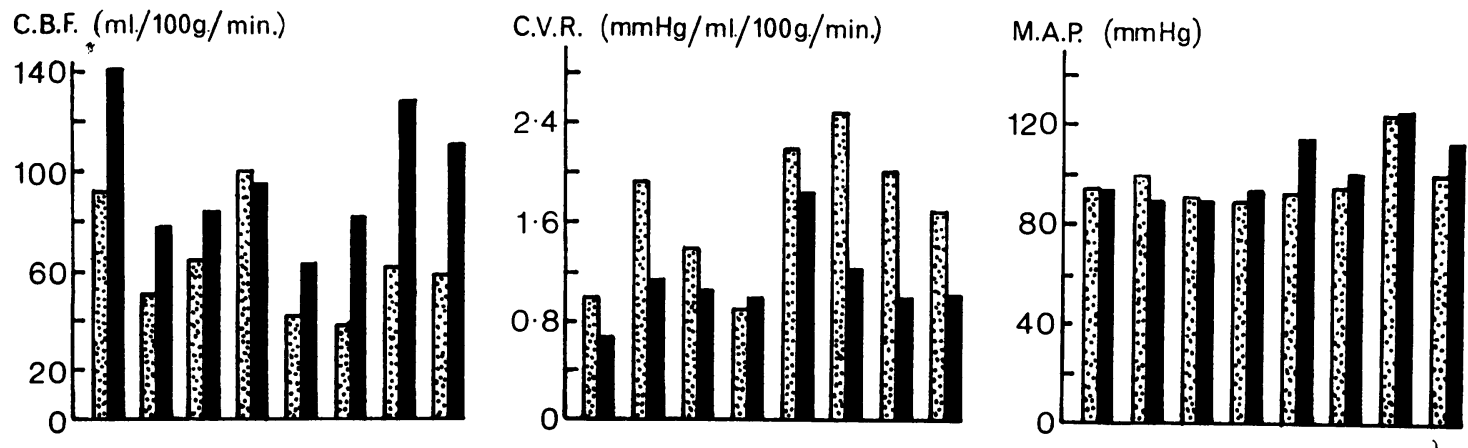

Before Portacaval anastomosis

After

FIG. 1. Cerebral blood flow (CBF), cerebral vascular resistance (CVR), and mean arterial pressure $(M A P)$ in eight patients affected by hepatic cirrhosis before and after portacaval anastomosis. 

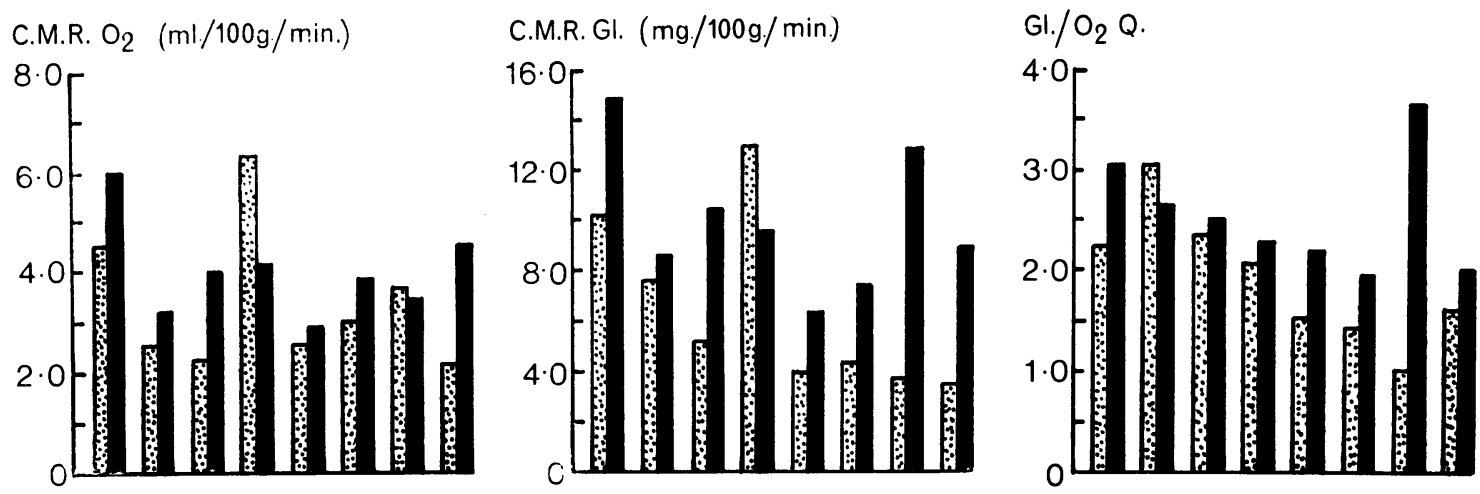

FIG. 2. Cerebral metabolic rate of oxygen $\left(\mathrm{CMRO}_{2}\right)$, cerebral metabolic rate of glucose (CMRGl), and glucose: oxygen quotient $\left(\mathrm{Gl} / \mathrm{O}_{2} Q\right)$ in eight patients affected by hepatic cirrhosis before and after portacaval anastomosis.

An increased concentration of vasoactive amines which, not catabolized by the shunted liver, reach the general circulation, can explain the peripheral vasodilatation (Kowalski and Abelmann, 1953); however, previous studies have demonstrated that the administration of histamine does not determine constant modifications of cerebral blood flow (Sokoloff, 1959).

The factors which have the greatest influence on the regulation of the cerebral haemodynamics are the arterial $\mathrm{pCO}_{2}$, the degree of hypoxia, and the blood viscosity. In our patients the arterial $\mathrm{pCO}_{2}$, oxygen volume, and oxygen saturation were the same before and after surgery (Table III). The

\section{TABLE III}

HAEMATOCRIT, ARTERIAL PCO $_{2}$, OXYGEN VOLUMES, AND SATURATION BEFORE AND AFTER PORTACAVAL ANASTOMOSIS (MEAN VALUES)

\begin{tabular}{lcccc} 
Hepatic Cirrhosis & Haematocrit & $\begin{array}{l}\text { Arterial } \\
p C O \\
(m m H g)\end{array} \begin{array}{l}\text { Arterial } \\
\text { Oxygen } \\
\text { vol } \%)\end{array}$ & $\begin{array}{l}\text { Arterial } \\
\text { Oxygen } \\
\text { Saturation (\%) }\end{array}$ \\
\hline $\begin{array}{l}\text { Before portacaval } \\
\text { anastomosis }\end{array}$ & 38 & 36 & $14 \cdot 2$ & 93 \\
$\begin{array}{l}\text { After portacaval } \\
\text { anastomosis }\end{array}$ & 33 & 36 & 13.5 & 95
\end{tabular}

haematocrit is reduced in patients with portacaval shunt but no significant correlation was found between the values for cerebral blood flow and for haematocrit $(r=-0.282)$. Finally, and we believe this is the most important factor, the increase in the cerebral blood flow seems due to local metabolic demands, both in order to remove toxic substances and to meet increased cerebral metabolic requirements.

It is known that patients undergoing this oper- ation are much more frequently affected by neuropsychiatric disturbances, usually attributed to a more prolonged or even higher level of ammonia in arterial blood. It is possible that this increased level of ammonia or of other substances, but always toxic to nerve cells, could be held responsible for the increase in the cerebral blood flow; however, we stress that a significant increase in both the metabolic rate of glucose and in the glucose : oxygen quotient was found simultaneously with the increase in cerebral blood flow. This observation suggests that, after surgery, some modifications in cerebral metabolism take place, and particularly that the excess glucose metabolized by the brain can be used to increase glutamine synthesis to neutralize faster ammonium compounds.

Our results appear to support the hypothesis that the increase in the cerebral blood flow observed in cirrhotic patients after portacaval shunt is essentially related to metabolic problems. This increase, besides accelerating the removal of toxic substances from the brain tissue, also places at the disposal of the brain metabolites capable of neutralizing these toxic substances.

We wish to express our appreciation to Professor E. E. Polli and Dr. L. Sokoloff for their advice and thoughtful criticisms.

\section{REFERENCES}

Delaney, J. P., Goodale, R. L., Jr., Cheng, J., and Wangensteen, O. H. (1965). Portacaval shunting and upper gastrointestinal blood flow. J. Amer. med. Ass., 192, 385-386.

Foda, H., Badawi, H., and Salah, M. (1964). Circulatory hemodynamics before and after portacaval shunt operation in bilharzial hepatic fibrosis. Amer. Heart J., 67, 295-303.

Gitlin, N., Grahame, G. R., Kreel, L., and Sherlock, S. (1968). Splenic blood flow and resistance in patients with well compensated cirrhosis before and after portacaval anastomosis. In 
3rd Meet. europ. Ass. Study Liver, Modena, September 19-22, abstract no 22.

Huggett, A. St. G., and Nixon, D. A. (1957). Use of glucose oxidase, peroxidase, and o-dianisidine in determination of blood and urinary glucose. Lancet, 2, 368-370.

Kety, S. S., and Schmidt, C. F. (1948). The nitrous oxide method for the quantitative determination of cerebral blood flow in man: theory, procedure and normal values. J. clin. Invest., 27, 476-483.
Kowalski, H. J., and Abelmann, W. H. (1953). The cardiac output at rest in Laennec's cirrhosis. J. clin. Invest., 32, 1025-1033.

Nylin, G. (1961). Discussion. Tavola rotonda sulle metodiche per lo studio del circolo viscerale. Minerva cardioangiol., 9, 712-716 and 734.

Van Slyke, D. D., and Neill, J. M. (1924). The determination of gases in blood and other solutions by vacuum extraction and manometric measurement. J. biol. Chem., 61, 523-573.

Sokoloff, L. (1959). The action of drugs on the cerebral circulation. Pharmacol. Rev., 11, 1-85. 